\title{
SISTEM PEMBUKTIAN TERBALIK ( SHIFTING THE BURDEN OF PROOF ) MENURUT UU NO 20 TAHUN 2001 JO UU NO 31 TAHUN 1999 TENTANG PEMBERANTASAN TINDAK PIDANA KORUPSI
}

Oleh :

ATET SUMANTO

\begin{abstract}
ABSRACT
That inversed verification according to UU No. 20 Year 2001 Jo UU No. 31 Year 1999 having the character of is limited, and proportional, its meaning of defendant have the right to prove that he do not corruption doing an injustice;

That besides defendant have the right to prove, he obliged to give boldness about entire/all its good and chattel and consort estae, child, and good and chattel each;every people /or anticipated corporation have link with case
\end{abstract}

key word : inversed verification, corruption, people/or corporation.

\section{PENDAHULUAN}

Korupsi, kolusi, dan nepotisme (KKN ) merupakan gejala masyarakat yang dapat dijumpai di seluruh antero jagat raya ini, seperti, pada NegaraNegara berkembang maupun maju dan sejarah peradaban manusia mem buktikan bahwa hampir setiap Negara dihadapkan pada masalah korupsi, kolusi, dan nepotisme yang tak kunjung selesai.

Berbicara tentang praktek korupsi, kolusi, dan nepotisme ( KKN ), maka tidak lepas dari upaya-upaya pemerintah dalam memberantas tindak pidana korupsi sampai pada akar- akarnya, sebagaimana yang diamanatkan dalam ketetapan MPR RI No. $\mathrm{XI} / \mathrm{MPR} / 1998$, tentang penyelenggara Negara yang bersih dan bebas korupsi, kolusi, dan nepotisme, dan dituangkan dalam Pasal 3, Pasal 4, dan Pasal 5 UU No. 28 Tahun 1999, akhirnya pemerintah memberitahu-kan sistem pembuktian terbalik (shifting the burden of proof), walaupun banyak pendapat para pakar hukum yang pro dan kontra, bahwasannya pembuktian tersebut menyimpang dari asas "praduga tak bersalah" yang dianut secara universal, ada sebagian masyarakat yang berasumsi dan ada juga yang khawatir bahwa dengan 
menerapkan sistem pembuktian terbalik (shifting the burden of proof) akan menimbulkan kesewenang-wenangan dari aparat penegak hukum, untuk mengeliminir hal itu perlu aparat penegak hukum yang professional.

Kondisi korupsi di Indonesia dalam keadaan menyedihkan dan sudah diambang kehancuran bukan lagi darurat, maka dalam situasi yang darurat pula pemerintah menerapkan sistem pembuktian terbalik ini (shifting the burden of proof),

Sebagaimana dalam penjelasan Undang-Undang Nomor 30 Tahun 2002 tentang komisi pemberantasan tindak pidana korupsi, yang telah disahkan serta diundangkan pada tanggal 27 desember 2002, dalam Lembaran Negara Republik Indonesia, tahun 2002, No. 137, menyebutkan, pada alinea ke-4, berbunyi sebagai berikut: "Pemerintah Indonesia telah meletakkan landasan kebijaksanaan yang kuat dalam usaha memerangi tindak pidana korupsi, berbagai kebijakan tersebut tertuang dalam berbagai peraturan perundang-undangan“ :

1. Ketetapan MPR RI No. X/MPR/1998, tentang penyelenggaraan Negara yang bersih dan bebas korupsi, kolusi, dan nepotisme.

2. UU No. 28 Tahun 1999 Tentang Penyelenggaraan Negara yang bersih dan bebas korupsi, kolusi, dan nepotisme.

3. UU No. 31 Tahun 1999 Tentang Pemberantasan tindak pidana korupsi.

4. UU No. 20 Tahun 2001 Tentang Pemberantasan tindak pidana korupsi.

Dari 4 ( empat ) landasan dalam upaya memerangi tindak pidana korupsi seperti diuraikan di atas, yang terpenting lagi adalah pembentukan Komisi Pemberantasan Tindak Pidana Korupsi (KPTPK) yang telah terealisasi/terwujud sebagaimana diatur dalam UU No. 30 Tahun 2002, yang mengatur keberadaan lembaga atau Badan Khusus, yaitu komisi PTPK tersebut bersifat independen dengan tugas dan wewenangnya.

Suatu lembaga komisi PTPK adalah badan khusus yang memiliki kewenangan melakukan koordinasi dan superfisi, termasuk melakukan : a)Penyelidikan ;b)Penyidikan ; dan c)Penuntutan;

Untuk mempertegas tugas dan atau kewenagan Lembaga atau Badan Khusus/Komisi PTPK, dalam melakukan 
penyelidikan, penyidikan, dan penuntutan

Tindak Pidana Korupsi, meliputi Tindak Pidana Korupsi yang:

a) Melibatkan aparat penegak hukum, penyelenggaraan Negara, dan orang lain yang ada kaitannya dengan Tindak Pidana Korupsi yang dilakukan oleh aparat penegak hukum atau penyelenggaraan Negara.

b) Mendapat perhatian yang dapat meresahkan masyarakat ; dan/atau.

c) Menyangkut kerugian Negara paling sedikit Rp. 1.000.000.000 (satu miliar rupiah)

Delik Korupsi adalah sebagaimana Delik Pidana pada umumnya dilakukan dengan berbagai modus operandi penyimpangan keuangan Negara atau perekonomian Negara, yang semakin canggih dan rumit, sehingga banyak kasus korupsi lolos dari "jaringan“ pembuktian sistem KUHAP (UndangUndang No. 8 tahun1981).

Karena itu pembuktian Undangundang mencoba menerapkan upaya hukum pembuktian terbalik (shifting the burden of proof), sebagaimana diterapkan dalam sistem beracara pidana di Negeri Jiran Malaysia, Thailand, Singapore, Hongkong, Korea Selatan dan Australia.

Berdasarkan pada uraian diatas

maka perlu dibahas tentang pembuktian terbalik yang diatur dalam UU No. 20 tahun 2001 Jo.UU no. 31 tahun 1999 tentang Pemberantasan Tindak Pidana Korupsi

Upaya pembentukan UU No. 20 tahun 2001 tidak tanggung-tanggung, karena baik dalam delik korupsi diterapkan dua sistem sekaligus yakni :

- $\quad$ Sistem Undang-Undang Nomor 20 tahun 2001 dan

- $\quad$ Sistem Undang-Undang Nomor 8 tahun 1981 tentang KUHAP

Kedua teori ini adalah penerapan hukum pembuktian dilakukan dengan cara-cara menerapkan :

1. Pembuktian terbalik yang bersifat terbatas atau berimbang

2. Menggunakan sistem pembuktian negatif menurut undang-Undang (Negative Wetterlijk overtuiging) Jadi tidak menerapkan teori pembuktian terbalik murni, (zuivere amskeering bewijstlast), tetapi teori pembuktian terbalik terbatas dan berimbang seperti terdapat dalam Pasal 
PERSPEKTIF Volume XI No.3 Tahun 2006 Edisi Juli

37a ( 1 ) dan (2) UU No. 20 Tahun 2001.

\section{RUANG LINGKUP DELIK YANG DAPAT DIPIDANA}

Ruang lingkup perbuatan yang dapat dipidana menurut Undang-undang No. 20 tahun 2001 tindak pidana korupsi, terdiri dari dua kelompok tindak pidananya itu :

1. Dalam bab II tentang tindak pidana korupsi, mulai Pasal 2 sampai dengan Pasal 20 Undang-Undang No. 20 tahun 2001 dan

2. Dalam bab III tentang tindak pidan yang lain yang berkaitan dengan tindak pidana korupsi diatur dalam Pasal 21 sampai dengan Pasal 24 Undang-Undang No.20 tahun 2001

\section{kelompok pertama}

Memuat 15 perumusan tindak pidana korupsi dalam Pasal 2 sampai dengan 16 Undang-Undang No. 20 tahun 2001, termasuk juga : percobaan, pembantuan, dan pemufakatan jahat, beserta aturan pemidanaanya dalam Pasal 17 sampai dengan Pasal 20 Undang-Undang No. 20 tahun 2001 kelompok kedua

Mengatur delik yang berhubungan dengan proses penyidikan dan penuntutan perkara korupsi, yaitu yang dilakukan oleh orang-orang yang menghalangi proses, si pengadu, saksi-saksi, dan aparat atau pejabat yang menangani perkara korupsi.

Tindak pidana yang dimasukkan dalam kelompok pertama, dalam UU No. 20 Tahun 2001 jo. UU No. 31 Tahun 1999 pada umumnya juga sama dengan UU No. 3 Tahun 1971, hanya saja dalam Pasal 15 UU No. 20 Tahun 2001 ada penambahan atau perluasan terhadap Pasal 1 sub 2 UU No. 3 Tahun 1971. Dalam Pasal 1 sub 2 UU No. 3 Tahun 1971 ditegaskan bahwa 'percobaan' dan 'permufakatan (jahat)', yang dipidana sama dengan delik pokoknya, sedangkan menurut UU korupsi terbaru (vide, Pasal 15 UU No. 20 Tahun 2001) diperluas pada 'pembantuan'. Dengan adanya perluasan tersebut, yaitu mengenai pemberatan pidana terhadap "pembantuan", harapan pembuat UU dapat lebih memberi pengaruh penangkal (seterrent effect) terhadap bentuk-bentuk kolusi, surat sakti atau bentuk-bentuk lainnya seperti, pemberian fasilitas atau kemudahan 
lainnya untuk melakukan korupsi.

Dalam Pasal 15 UU No. 20 Tahun 2001, adanya penambahan atau perluasan pada "pembantuan", sesuai dengan rekomendasi Kongres PBB ke VIII, yakni : "Recommendations on international cooperation for crime prevention and criminal justice in the context of developmen "yang artinya dalam rekomendasi konggres PBB tersebut diharapkan agar peraturan yang dibuat (di "review") mampu menanggulangi perbuatan "membantu atau mempermudah dan atau memberi fasilitas terjadinya Tindak Pidana Korupsi " (to assist or to facilitate corrupt activitie ).

Dalam penjelasan atas UU No. 20

Tahun 2001 dikatakan, pengertian "Pembuktian terbalik yang bersifat terbatas dan berimbang", yakni terdakwa mempunyai hak untuk membuktikan bahwa ia tidak melakukan tindak pidana korupsi dan wajib memberikan keterangan tentang seluruh harta bendanya dan harta benda istrinya atau suami, anak dan harta benda setiap orang atau korporasi yang diduga mempunyai hubungan dengan perkara yang bersangkutan dan Jaksa Penuntut Umum tetap berkewajiban untuk membuktikan dakwaannya.
Dalam pemeriksaan delik korupsi ada 2 (dua) hukum acara pidana :

1. Hukum acara pidana yang tercermin alam Undang-Undang Nomor 20 Tahun 2001 sebagai penyimpangan dari UndangUndang Nomor 8 Tahun 1981;

2. Hukum acara pidana yang termuat dalam Kitab Undang-Undang Hukum Acara Pidana (KUHAP) yaitu Undang-Undang Nomor 8 Tahun 1981.

\section{MASALAH PERUMUSAN DELIK DAN KUALIFIKASI DELIK}

\section{a. Perumusan Delik}

Untuk lebih mengefektifkan pemberantasan tindak pidana korupsi, perumusan delik dalam UU No. 3 Tahun 1971 pernah dikritisi agar dijadikan saja "delik formal" dengan mengubah unsur "yang merugikan uang Negara" menjadi "yang dapat merugikan keuangan Negara" dan diusulkan suatu klausul yang menegaskan : "Bahwa pengembalian keuangan negara tidak menghapuskan dapat dipidananya tindak pidana".

Akhirnya usulan atau kritikan tersebut telah tertampung dalam perumusan Pasal 2, Pasal 3, dan Pasal 4 
UU No. 31 Tahun 1999.

Selain itu upaya pemberantasan "Nepotisme", pernah diusulkan agar unsur adanya nepotisme itu dirumuskan secara eksplisit dalam perubahan Pasal 1 sub $1 \mathrm{a}$ dan 1b UU No. 3 Tahun 1971

Namun, usul perubahan diatas tidak ditampung dalam perumusan Pasal 2 dan Pasal 3 UU No. 20 Tahun 2001 Jo UU No. 31 Tahun 1999. Mungkin pembuat UU TPK memandang cukup, bahwa unsur nepotisme itu sudah tercakup dalam unsur-unsur "orang yang ada dalam perumusan delik yang bersangkutan".

Delik korupsi yang dirumuskan dalam Pasal 1 sub 1e UU No. 3 Tahun 1971, yaitu pejabat yang melaporkan kepada yang berwajib setelah menerima pemberian atau janji, dalam Pasal 418, Pasal 419, dan Pasal 420 KUHP, tidak lagi dijadikan tindak pidana korupsi, menurut UU No. 20 Tahun 1999.

Hal ini talah sesuai dengan usulan atau kritikan yang sering dikemukakan, bahwa perbuatan terlarang dalam Pasal itu tidak mungkin terjadi, alasannya karena apabila si pejabat itu melapor, dia sendiri dapat terjerat dengan Pasal 1 sub 1c UU No. 3 Tahun 197-Jo-(vide, Pasal 418, 419, dan 420 KUHP).
Hal itu telah ditegaskan dalam penjelasan Pasal 1 sub 1c UU No. 3 Tahun 1971, berbunyi : Bahwa tiap pelapor tentang penerimaan atau pemberian atau janji itu tidak berarti membebaskan terdakwa dari kemungkinan penuntut umum berdasarkan Pasal 418, 419, dan 420 KUHP.

\section{b. Kualifikasi Delik}

Dalam UU No. 3 Tahun 1971, ditegaskan : Bahwa semua tindak pidana korupsi dinyatakan sebagai "kejahatan", (vide, Pasal 33 No. 3 Tahun 1971), sangat disayangkan penegasan seperti itu, tidak ada dalam UU No. 31 Tahun 1999, maupun dalam perubahannya UU No. 20 Tahun 2001. Hal ini bisa menimbulkan masalah, karena peraturan perundangan pidana diluar KUHP tetap terikat pada aturan umum KUHP, mengenai akibat-akibat dari pembedaan antara "kejahatan" disatu sisi dan "pelanggaran" disisi lain.

Tidak ditegaskan kualifikasi delik korupsi dalam UU No. 31 Tahun 1999 maupun dalam UU No. 20 Tahun 2001, menurut penulis kemungkinan sebagai "kejahatan", karena UU sudah tidak lagi membedakan akibat hukum pemidanaan 
"percobaan" dan "pembantuan" yaitu : kedua-duanya diancam pidana sama dengan pelaku delik. Padahal, akibat hukum dari pembedaan "kejahatan" dan "pelanggaran", bukan pada masalah "percobaan dan/ atau pembantuan", tetapi juga pada masalah - masalah lain:1. ada concursus;2. daluwarsa penuntut-an; 3. pelaksanaan pidana;4. berlakunya "asas nasional aktif" sebagaimana diatur dalam Pasal 5 ayat (1) ke-2 KUHP, dan sebagainya.

Penetapan kualifikasi delik sebagai "kejahatan", merupakan penetapan kualifikasi yuridis, yang mempunyai akibat atau konsekuensi yuridis, baik dalam arti konsekuensi yuridis materiil, yaitu terikat pada aturan umum dalam KUHP, maupun konsekuensi yuridis formal, (dalam KUHP), sepanjang tidak ditentukan lain oleh undangundang.

Penetapan kualifikasi yuridis ini diperlukan untuk menjebatani berlakunya aturan umum KUHP terhadap hal-hal yang tidak diatur dalam undang-undang diluar KUHP, jadi identik dengan penetapan kualifikasi yuridis terhadap suatu perbuatan sebagai :"tindak pidana ekonami " atau"tindak pidana korupsi"

Yang juga mempunyai akibat yuridis, yaitu :

1. apabila undang-undang diluar Undang-Undang Nomor 7 Darurat Tahun 1955, menyebutkan/menyatakan, bahwa suatu delik adalah tindak pidana ekonomi, maka berlakulah ketentuan-ketentuan dalam Undang-Undang Tindak Pidana Ekonomi; (vide, Pasal 1-subjek Undang-Undang Nomor 7 Darurat Tahun 1955).

2. apabila undang-undang diluar Undang-Undang Nomor 31 Tahun 1999 Jo Undang-Undang Nomor 20 Tahun 2001. menyebutkan/menytakan bahwa suatu delik adalah tindak pidana korupsi, maka berlakulah ketentuan dalam UndangUndang Tindak Pidana Korupsi; (vide, Pasal 14 Undang-Undang Nomor 20 Tahun 2001 Jo Undang-Undang Nomor 31 Tahun 1999). 
Demikian pulalah dengan ketentuan dalam KUHP, karena aturan umum KUHP membedakan antara "aturan umum untuk kejahatan" dan "aturan umum untuk pelanggaran", maka apabila aturan umum KUHP itu akan juga diberlakukan terhadap undang-undang diluar KUHP (berdasarkan Pasal 103 KUHP), maka undang-undang diluar KUHP itu juga harus menyebut kualifikasi yang jelas dari tindak pidana yang diaturnya, apakah merupakan "kejahatan" atau "pelanggaran".

\section{A. Subyek Tindak Pidana Korupsi}

Dalam UU No. 31 TAhun 1999 juncto UU No. 20 Tahun 2001, kalau dibandingkan dengan UU No. 3 Tahun 1971, adanya perubahan terhadap subyeknya, antar lain yaitu : Bahwa subyek tindak pidana korupsi tidak hanya "orang perorangan" tetapi juga "korporasi", sedangkan yang dimaksud dengan "korporasi" ialah kumpulan orang atau kekayaan terorganisasi, baik merupakan badan hukum maupun bukan badan hukum (vide, Pasal 1 ke-1 UU No. 20 Tahun 2001).

Dapat dikenakan sanksi pidana atau tindakan kepada korporasi dalam perkara korupsi adalah cukup beralasan dan hal ini sesuai dengan beberapa rekomendasi Kongres $\mathrm{PBB}$ yaitu mengenai "The Prevention of Crime the Treatment of Fenders";

Dalam dokumen Kongres PBB ke IX tahun 1995, di Kairo antara lain ditegaskan :

"Korporasi, assosiasi criminal atau individu mungkin terlibat dalam "penyuapan para pejabat", untuk berbagai alasan yang tidak semuanya bersifat ekonomi, namun dalam banyak kasus, masih saja penyuapan digunakan untuk mencapai keuntungan ekonomis, dan tujuannya ialah membujuk para pejabat untuk memberikan berbagai bentuk perlakuan khusus atau istimew (prefenstial treatment),

\section{B. Perumusan Pidana Dan Pemidanaan}

Masalah sistem perumusan pidana dan pemidanaan antara UU No. 3 Tahun 1971 berbeda dengan UU No. 20 Tahun 2001 Jo UU No. 31 Tahun 1999, dalam Undang-Undang Korupsi yang terbaru setiap delik dirumuskan dalam satu pasal tersendiri disertai dengan ancaman pidananya. Jadi sistem perumusan pidananya menggunakan 
sistem absolut/ mutlak, sedangkan dalam UU No. 3 Tahun 1971 menggunakan relative/nisbi. Selain itu Undang-Undang Korupsi terbaru menggunakan ancaman pidana minimal khusu (kecuali dalam 2 Pasal, masing-masing : Pasal 13 dan Pasal 24 UU No. 20 Tahun 2001) sedangkan dalam UU No. 3 Tahun 1971 tidak menggunakan pidana minimal khusus.

Penggunaan ancaman pidana minimal khusus dalam tindak pidana korupsi, seperti dalam undang-undang lainnya, antara lain :

- Undang-Undang Narkotika;

- Undang-ndang Psikotropika;

- Undang-Undang Perbankan;

- Undang-Undang Lingkungan

Hidup dan lain sebagainya.

Adalah cukup beralasan, namun sangat disayangkan adanya ancaman pidana minimal khusus diberbagai undang-undang tersebut, termasuk Undang-Undang tentang Korupsi, tidak disertai dengan aturan atau pedoman pemidanaan untuk menerapkan ancaman pidana minimal khusus dimaksud.

Dengan adanya sistem pidana minimal khusus aturan tersendiri dalam dan untuk penerapannya, dan hal ini merupakan konsekuensi dari adanya
Pasal 103 KUHP, karena dalam KUHP tidak diatur tentang masalah tersebut.

Dengan tidak adanya pedoman dalam penanganan sanksi pemidanaan seperti diuraikan di atas, maka tidak begitu jelas apakah pidana minimal itu dapat diperingan (adanya factor/unsur yang meringankan) ataukah dapat diperberat (adanya factor atau unsur pemberat). Tidak adanya pedoman pemidanaan ini (dalam UU No. 20 Tahun 2001), kemungkinan pembuat undang-undang sudah merasa membuat ketentuanetentuan, yaitu :

1. percobaan

2. pembantuan, dan

3. permufakatan hal tersebut dapat dipidana sama berat dengan pelaku (vide, Pasal 15 UU No. 20 Tahun 2001); Jadi pembuat undang-undang tidak memandang, percobaan, pembantun, dan permufakatan jahat, itu sebagai faktor-faktor yang meringankan pidana, sehingga dipandang tidak perlu membuat aturan khusus untuk menerapkan sistem pidana minimal terhadap ketiga unsur/faktor yang meringankan itu. Namun patut dipahami/dicatat, bahwa faktor yang meringankan itu tidak hanya ketiga faktor obyektif seperti diuraikan di 
atas, bahkan dalam penjelasan Pasal 4 UU No. Tahun 2001, disebutkan adanya faktor obyektif lainnya yang dapat menjadi faktor meringankan, yaitu :

1. adanya pengembalian kerugian keuangan atau perekonomian negara;

2. subyektifitas pelaku/terdakwa tindak pidana korupsi.

Dengan adanya faktorfaktor yang meringankan tersebut, maka akan menjadi persoalan baru, yaitu : "Apakah pidana minimal khusus itu juga dapat diperingan ?".

Demikian pula dengan adanya faktor-faktor yanmg memberatkan pelaku /Terdakwa, berupa keadaan tertentu, seperti disertakan dalam penjelasan Pasal 2 ayat (2) Undang-Undang No. 20 tahun 2001 disebutkan :

"dilakukan pada waktu negara dalam keadaan bahaya, pada waktu terjadi bencana alam nasional, pengulangan, negara dalam keadaan krisis ekonomi dan moneter".

Sehingga, menurut Pasal 2 ayat (2) UU No. 20 Tahun 2001, apabila tindak pidana korupsi pada ayat (1) dilakukan dalam keadaan tertentu, maka maksimum pidananya diperberat dengan pidana/ hukuman mati, akankah menjadi polemic/masalah, apakah pidana minimalnya juga dapat diperberat, demikian pula timbul masalah baru, yaitu apakah pidana minimal khusus dapat diperberat apabila ada alasan pemberatan pidana berupa "perbarengan atau concursus".

Dengan demikian ada kejanggalan dan ketidak jelasan, antara lain :

1. Ada delik dengan ancaman minimal 20 tahun penjara;

2. Ada pidana minimal 4 tahun; (vide, Pasal 12 UU No. 20 Tahun 2001);

3. Ada pidana minimal 1 tahun;

4. Pidana minimal 1 tahun diancamkan untuk delik yang ancaman pidana maksimal 5 tahun penjara; (vide; Pasal 9 dan Pasal 11 UU No. 20 Tahun 2001);

5. Menggunakan sistem kumulatif, danl

6. Sistem kumulatif-alternative (gabungan).

Dengan demikian, masalahnya adalah mengapa delik korupsi berupa, memperkaya diri sendiri diancam pidana 
secara kumulatif, sedangkan menyalah gunakan kewenangan jabatan atau kedudukan, diancam pidana secara kumulatif-alternatif (gabungan), padahal dilihat dari ancaman pidananya/bobot deliknya sama, maka secara teoritik delik dengan pidana secara kumulatif dan dengan kumulatif-alternatif adalah lebih berat ancaman kumulatif daripada kumulatif-alternatif (gabungan).

\section{TEORI TENTANG PEMBUKTIAN TERBALIK}

Dalam pembuktian perkara pidana pada umumnya dan khususnya delik tindak pidana korupsi, diterapkan UU No. 8 Tahun 1981 (KUHAP), sedangkan dalam pemeriksaan delik tindak pidana korupsi selain diterapkan UU No. 8 Tahun 1981 (KUHAP), diterapkan juga sekelumit hukum acara pidana, yaitu pada Bab IV terdiri atas Pasal 25 sampai dengan Pasal 40 UU No. 20 Tahun 2001 Jo UU No. 31 Tahun 1999, yang antara lain :

- Pasal 25 UU No. 20 Tahun 2001 Jo UU No. 31 Tahun 1999, disebutkan:

- Pasal 26, disebutkan : Penyidikan, penuntutan, dan pemeriksaan di sidang pengadilan terhadap tindak pidana korupsi, dilakukan berdasarkan hukum acara pidana yang berlaku, kecuali ditentukan lain dalam UU ini;

Selanjutnya dalam Pasal 40 UU No. 31/1999 jo. UU No. 20/ 2001, menunjuk bahwa dalam mengenai perkara koneksitas dan terdapat cukup alasan untuk mengajukan perkara korupsi di lingkungan peradilan militer, maka ketentuan yang dimaksud dalam Pasal 123 ayat (1) huruf (g) UU No. 31 / 1997 tentang peradilan militer tidak dapat diberlakukan.

Ada beberapa teori atau system pembuktian, yakni :

\section{Teori Tradisional}

$B$ de Bosh Kemper, menyebutkan ada beberapa teori tentang pembuktian yang tradisional, meliputi :
a. Teori Negatif ;
b. Teori Positif; dan
c. Teori Bebas.

\section{Teori Modern \\ Perkembangan teori selalu dimungkinkan dan akhir-akhir ini berkembang suatu teori baru, meliputi :}


1. Teori Pembuktian Dengan Keyakinan Belaka;

2. Teori Pembuktian Menurut UU Secara Positif ;

3. Teori Pembuktian Menurut UU Secara Negatif;

4. Teori Keyakinan Atas Alasan Negatif;

5. Teori Pembuktian Negatif Menurut UU; dan

6. Teori Pembuktian Terbalik ; (Wiryono Prodjodikiro, 1962: 71)

\section{Ad. 1. Teori Pembuktian Dengan} Keyakinan Belaka (Bloot Gemeodelijke Overtuiging/ Conviction Intime).

Aliran ini tidak membutuhkan suatu peraturan tentang pembuktian dan menyerahkan segala sesuatunya kepada kebijaksanaan hakim, dan terkesan hakim sangat bersifat subyektif.

Menurut aliran ini sudah dianggap cukup, bahwa hakim mendasarkan terbuktinya suatu keadaan atas keyakinan belaka, dengan tidak terikat oleh suatu peraturan.

Dalam sistem ini, hakim dapat menurut perasaan belaka dalam menentukan apakah keadaan harus dianggap telah terbukti, karena aliran ini disebut convention intime atau bloote gemoedelijke overtuiging.

\section{Ad. 2. Teori Pembuktian Menurut UU Secara Positif (Positif WetterlijkeBewijstheorie).}

Aliran sistem pembuktian menurut UU secara positif atau disebut juga positief wetterlijke bewijstheorie, dalam teori ini UU menetapkan alat-alat bukti mana yang dapat dipakai oleh hakim, dan cara bagaimana hakim mempergunakan alat-alat bukti serta kekuatan pembuktian dari alat-alat itu sedemikian rupa. D. Simons, menyatakan :"Bahwa system positief wetterlijke di benua Eropa dipakai pada waktu berlakunya hukum acara pidana yang bersifat "inguisitor", peraturan itu menganggap terdakwa sebagai obyek pemeriksaan belaka, dalam hal ini hakim hanya merupakan alat pelengkap saja. (Wiryono Prodjodikiro,1962: 72)

Ad. 3. Teori Pembuktian Menurut UU Secara Negatif (Negatief Wetterlijke Bewijstheorie).

Ad. 4. Teori Keyakinan Atas Alasan Logis (Beredeneerde Nertuging/ 


\section{Convection Raisonnee).}

Kedua teori pembuktian ini, jika diperbandingkan kedapatan adanya hal yang persamaan dan perbedaan.

\section{Persamaannya}

Dalam hal ini hakim harus diwajibkan menghukum orang, apabila ia yakin bahwa perbuatan yang bersangkutan terbukti kebenarannya dan lagi bahwa keyakinan harus disertai penyebutan alasan-alasan yang berdasarkan atas suatu rangkaian buah pikiran (logika).

\section{Perbedaannya}

Dalam hal ini pada teori pembuktian menurut UU secara negatief menghendaki alasan-alasan yang disebutkan oleh UU sebagai alat bukti (wetterlijk bewijsmiddelen). Tidak diperbolehkan menggunakan alat bukti lain yang tidak disebut dalam UU dan tentang cara mempergunakan alat bukti (bewijstvoering), hakim terikat kepada ketentuan UU. Istilah "negatief " dipakai oleh karena adanya alat-alat bukti yang disebut dalam UU, hal ini belum berarti hakim mesti menjatuhkan pidana, ini tergantung pada keyakinan hakim atas kebenaran.

\section{Ad.5.Teori pembuktian Negatif menurut Undang-Undang ( Negatief Wetterlijke Overtiging )}

KUHAP maupun HTR, menganut teori yang sama yaitu teori negative menurut UU kedua-duanya memiliki persamaan dalam system dan cara mengunakan alat-alat bukti, yakni teori pembuktian negative menurut UU.hal itu ternyata dalam Pasal 183 UU No.8 / 1981 sama dengan Pasal 294 ayat 1 HTR.

Pasal 183 UU No. 8 tahun 1981, berbunyi :

" hakim tidak boleh menjalankan pidana kepada seseorang, kecuali apabila dengan sekurang-kurangnya 2 (dua) alat bukti yang sah ia memperoleh keyakinan, bahwa suatu tindak pidana benar-benar terjadi dan bahwa terdakwalah yang bersalah melakukannya."

\section{Ad.6. teori pembuktian terbalik ( Omkering Van Hel Bewijs Theori)}

Dalam Pasal 128 ayat 1 UU No. 20 /2001 dikenal istilah "Gratifikasi" yang diintrodusir dalamUndang-Undang 
Tindak Pidana Korupsi, dalam penjelasannya memberikan pengertian sebagai berikut :

Yang dimaksud dengan Gratifikasi dalam ayat ini adalah pemberian dalam arti yang luas, yakni meliputi :

- pemberian uang; barang; rabat (discount); komisi; pinjaman tanpa bunga; tiket perjalanan; fasilitas; penginapan; perjalanan wisata; pengobatan Cuma-Cuma; dan fasilitas lainnya.

Gratifikasi tersebut baik yang diterima di dalam negeri maupun di luar negeri dan yang dilakukan menggunakan saran alektronik atau tanpa sarana elektronik.

Sebenarnya kalau ditelaah, pengertian gratifikasi itu sendiri bukan merupakan suatu bentuk dan atau jenis kejahatan korupsi, sepanjang penerimaan gratifikasi tidak berhhubungan dengan jabatannya dan yang berkenaan dengan kewajiban serta gratifikasi tersebut dilaporkan pada Komisi Pemberantasan Tindak Pidana Korupsi.

Apabila si penerima gratifikasi tidak melaporkan gratifikasi tersebut, maka terhadap yang bersangkutan dikenakan dugaan tindak pidana korupsi berdasrkan Pasal 419 KUHP (untuk Pegawai Negeri/PNS ), jo. Pasal 420 KUHP (untuk hakim), yang telah diintrodusir ke dalam Pasal 12.b UU No. $20 / 2001$.

Sebaliknya daripada itu, bagi si penerima gratifikasi wajib membuktikan bahwa pemberian itu bukanlah korupsi (suap/bribery), artinya si penerima gratifikasi wajib membuktikan bahwa pemberian itu tidak berlawanan dengan jabatan dan tidak berlawanan dengan kewajiban atau tugasnya, sedangkan untuk unsure menerima hadiah atau janji tetap harus ada dugaan lebih dahulu dari jaksa penuntut umum.

Ada 3 (tiga) unsur essensial dari delik suap (bribery), yaitu :

1. menerima hadiah atau janji;

2. berkaitan dengan kekuasaan yang melekat pada jabatan;

3. bertentangan dengan kewajiban dan tugasnya;

Dari ketiga unsur tersebut, penerima gratifikasi harus bisa membuktikan bahwa pemberian tersebut tidak bertentangan dengan dan atau berlawanan dengan unsur (2) dan (3) dan apabila hal itu dapat dibuktikan, maka dakwaan jaksa tidak terbukti (vide, Pasal 
137 ayat (2) UU No. 31 / 1999).

Sebaliknya, apabila penerima gratifikasi mempergunakan hak untuk membuktikan bahwa ia tidak melakukan Tindak Pidana Korupsi, yaitu dengan cara melaporkan kepada PTPK, maka terhadap dirinya belum terjadi delik, dalam hal ini tidak dapat diartikan telah terjadi "pemutihan", karena delik suap belum terjadi pada diri penerima gratifikasi.

Dalam Pasal 12.B UU No.21 / 2001, berbunyi : "Setiap gratifikasi kepada Pegawai Negeri atau penyelenggara Negara dianggap pemberian suap, apabila berhubungan dengan jabatannya dan yang berwenang dengan kewajibannya atau tugasnya ", dengan ketentuan sebagai berikut :

a. yang nilainya Rp. $10.000 .000,00$ (sepuluh juta rupiah), atau lebih pembuktian gratifikasi tersebut bukan merupakan suap dilakukan oleh penerima gratifikasi.

b. Yang nilainya kurang $\mathrm{Rp}$. 10.000.000, 00 (sepuluh juta rupiah) membuktikan bahwa gratifikasi tersebut suap dilakukan oleh penuntut umum.

Menurut ketentuan Pasal 12.b UU No. 20 / 2001 tidak berlaku bilamana penerima gratifikasi tersebut melaporkan kepada komisi PTPK, karena komisi ini akan melakukan penilaian terhadap gratifikasi tersebut, apakah gratifikasi sah atau gratifikasi tersebut termasuk gratifikasi suap (bribery), apabila penilaian dihasilkan putusaan bahwa gratifikasi tersebut sah, maka gratifikasi tersebut dapat menjadi milik penerima. Hal tersebut berbeda manakala gratifikasi tersebut dinyatakan sebagai suap, maka gratifikasi tersebut milik Negara (vide, Pasal 12.c UU No. 20 / 2001).

UUPK Malaysia mengatur tentang pembuktian terbalik yang terbatas, karena hanya meliputi suap menyuap dan atau pemberian (gratification) saja. Tidak meliputi semua jenis korupsi. Pembuktian terbalik terbatas dan atau mereka sebut sebagai presumption of corruption itu tercantum di dalam Pasal 14 UUPK Malaysia, yang lengkapnya berbunyi sebagai berikut :

"Where in any proceedings against a person for an offence under section 3 or 4 it is provet that any gtativication has been pai or given to or received by a person in the employment of any public body, the gratification shall be deemed to have been paid or given and recived corruptly as an inducement or reward as here in before 
mentioned, unless the contrary is proved".

Bunyi Pasal di atas adalah benarbenar merupakan pembuktian terbalik, artinya suatu pemberian (gratifikasi) itu dianggap diberikan sebagai suap dan atau korupsi sampai terdakwa (si penerima) membuktikan sebaliknya bahwa itu diberikan bukan sebagai suap, lagipula pemberian itu harus dilaporkan dalam kesempatan pertama kepada polisi terdekat menurut UUPK Malaysia. Jadi kalau menerima suatu pemberian yang tergolong suap tetapi tidak dilaporkan, maka terjadilah delik ganda, sama halnya dengan UUPK Indonesia yaitu :

1. delik suap; dan

2. delik tidak melaporkan pemberian ( suap ) yang diterima dan atau dijanjikan.

Menurut penjelasan Direktur Jendral Badan Pencegah Resuah, pada tahun 1985 di Kuala Lumpur, jika yang menerima pemberian (Gratification) itu melaporkan pada kesempatan pertama, maka ada dua kemungkinan :

1. jika nilai barang kecil yang dapat dipandang sebagai souvenir saja, seperti dasi, setelan cangkir, dll, maka penerima dapat membawa pulang ke rumah dan dicatat di BPR itu, jadi semacam pemutihan;
2. jika barang itu besar nilainya seperi rumah, tanah, dll, maka pada waktu dilaporkan dibalik nama atas nama Negara.

Menurut penjelasan oleh karena itu, dalam hal usaha memberantas korupsi perlu ada suatu system pendaftaran harta benda para pejabat ( Government Official dan atau penyelenggara Negara ) sebagai tindakan preventif, sedangkan penuntutan dan atau penjatuhan pidana merupakan " Ultimum Temedium “.

Seperti halnya Malaysia, Thailand mengenal pula pembuktian terbalik terbatas, yaitu ketentuan bahwa terdakwa mempunyai kewajiban bahwa harta bendanya diperoleh secara sah. Jika terdakwa tidak dapat membuktikannya, maka harta benda itu akan disita untuk Negara. Di Thailand UU anti korupsinya disebut the Thai Counter Corruption Comision ( C.C.C ). Jika CCC menemukan seseorang yang melakukan delik korupsi, maka akan dilaporkannya kepada penuntut umum dan memohon kepada pengadilan untuk menyita harta benda orang tersebut. Dan bersamaan dengan itu, CCC mengirim bukti-bukti kepada polisi untuk penyidikan. Juga mempunyai wewenang untuk membuat usul kepada 
dewan menteri.

Jika polisi yang menemukan bahwa seseorang telah menjadi kaya karena melakukan korupsi, maka polisi akan melaporkan kepada penuntut umum yang selanjutnya menuntut ke pengadilan supaya harta benda orang itu disita. Jika polisi tidak dapat membuktikan bahwa harta benda itu diperoleh dari korupsi, maka ia hanya dapat melapor CCC Badan inilah yang akan menyidik asal-usul harta bendaorang tersebut, yang selanjutnya mengirimkan kepada penuntut umum. Seperti hanyalah dengan Thailand, hongkong tidak mempunyai anti UndangUndang korupsi yang khusus diciptakan rumusan delik korupsi seperti di Indonesia dan Malaysia.

Hongkong hanya mendirikan suatu badan khusus yang menyidik delik tertentu yang sudah ada UndangUndangnya, seperti : Bribery Ordinance " theft ordinance", etc. Didalam "Bribery ordinance" itulah terdapat rumusan delik korupsi yang pada umumnya hanya menyangkut suap atau pemberian (Gratification). Mirip dengan Malaysia, "Bribery Ordinance" ini juga menganut pembuktian terbalik terbatas, yaitu seorang pegawai negeri (crown servant) yang memiliki kekayaan lebih dari penghasilan yang resmi tidak dsapat member penjelasan dipengadilan mengenai asal-usul kelebihan kekayaan tersebut (Pasal 10, "bribery Ordinance"), begitu pula pegawai perusahaan swasta yang menerima komisi dalam melakukan pekerjaan yang diadakan oleh majikan/pengusaha (Pasal 9, "Bribery Ordinance"). Hongkong suatu koloni yang hidup dari perdagangan dan industri, karena itu segala kecurangan dibidang perdagangan dan industry dipandang sangat berbahaya bagi interest mereka itu, maka pantaslah kalau korupsi dikalangan swasta atau bisnis pun dipandang sangat perlu untuk diberantas, bukan saja korusi dikalangan pegawai negeri atau pejabat yang mengerogoti keuangan dan perekonomian Negara yang dipandang sebagai korupsi.

Undang-Undang khusus pemberantasan korupsi yang disebut dengan "The Procceds of crime act, 1987" di Australia adalah merupakan pola paket tindakan-tindakan yang dimaksud meningkatkan kemampuan penegak hukum untuk memerangi, khususnya terorganisaikan (Organized Crime) dan korupsi serta sebagai penjera agar orang lain tidak mengambil bagian dalam aktifitas seperti itu. Jadi dapat dikatakan 
PERSPEKTIF Volume XI No.3 Tahun 2006 Edisi Juli

bahwa Undang-undang Australia ini bersifat luas, pesperentif, represif dan transansional, artinya berlakunya dapat melampaui batas-batas Negara berdasarkan kerjasama dengan Negara lain yang didasarkan atas "mutual assintance act" , The Proceeds of Crime Act. Juga menciptakan dua delik baru menyangkut money laundry yakni :

1. kejahatan yang dilakukan dalam keadaan bahwa seseorangl mengetahui/patut dapat mengetahui bahwa harta benda diperoleh dari perbuatan melanggar hukum.

2. Kejahatan yang seseorang menerima, menguasai, menyembunyikan, mebelanjakan atau membayar ke Australia uang atau harta benda lain yang patut dapat disangkakan sebagai pelaksana kejahatan, kalau ia dapat meyakinkan hakim bahwa uang itu bukan diperoleh langsung atau tidak langsung dari perbuatan melawan hukum, ia dapat dibebaskan.

3. perjanjian saling membantu antara Australia dengan Negaranegara lain, Italia, Lexumbourg, Netherland, Philipina, Inggris,
Argentina, Finlandia, Portugal, Spanyol, Swiss, Yunani, Maroko, Canada ,Swedia, German, Belgia, Denmark, France, Norwegia, Lichtenstein, Thailand, Korea Selatan dan USA. Tentang ketentuan mengenai kewajiban penyelenggaraan Negara dalam hal ini meliputi pejabat Negara pada lembaga tinggi Negara pada lembaga tertinggi Negara. Pejabat Negara pada lembaga tinggi Negara, gubernur, hakim, pejabat Negara yang lain sesuai dengan ketentuan peraturan perundangundangan yang berlaku dan pejabat lain yang memilikifungsi strategis dalam kaitannya dengan penyelenggaraan Negara sesuai dengan ketentuan peraturan perundang-undangan yang berlaku (vide, Pasal 2 UU no. 28 tahun 1990).

Jadi penyelenggara Negara yang dimaksud adalah pejabat yang menjalankan fungsi eksekutif, legislative atau yudikatif dan pejabat lain yang fungsi dan tugas pokoknya berkaitan dengan penyelenggaraan Negara sesuai dengan ketentuan peraturan perundangundangan yang berlaku. Untuk melapor- 
PERSPEKTIF Volume XI No.3 Tahun 2006 Edisi Juli

kan dan mengumumkan kekayaan sebelum dan setelah menjabat telah ditentukan dan/atau diatur dalam Pasal 5 ayat 3 UU No. 28 tahun 1999 tentang penyelenggaraan Negara yang bersih dan bebas dari korupsi, kolusi dan nepotisme yang disahkan pada tanggal 19 mei 1999 (lenbara Negara repulik Indonesia tahun 1999 Nomor 75).

Kembali pada persoalan poko penbahasan, bahwa sistem pembuktian terbalik (sifting the burden of proof) terbatas dan berimbang, maka bagaimana pelaku-pelaku UU No. 20 tahun 2001 Jo. UU No. 31 tahun 1999, terhadap wacana itu, mungkin penulis dapat meng-gambarkan hal-hal sebagi berikut

\section{Sikap terdakwa}

Bagi terdakwa, wacana demikian ada seyoggisnys ysng perlu diperhatikan dalam memilih alternative, apakah ia akan menggunakan hak itu atau tidak, karena menggunakan hak atau tidak semua ada konsekwensinya. Dalam menggunakan hak tersebut, ada dua hal harus diperhatikan oleh terdakwa yakni :

a. Untuk membuktikan bahwa ia tidak melakukan delik korupsi sebagai-mana didakwakan oleh JPU

b. la berkewajiban untuk memberikan keterangan seluruh harta bendanya sendiri, harta benda istrinya, atau suaminya jika terdakwa adalah perempuan anakanaknya dan harta benda setiap orang atau korporasi yang diduga ada kaitanya dengan perkara yang bersangkutan.

\section{Syarat Pertama}

Syarat ini merupakan suatu penyimpangan dari ketentuan KUHP yang menetukan bahwa penuntut umum dilakukan tindak pidana, bukan terdakwa. Menurut ketentuan ini terdakwa dapat membuktikan dalilnya, bahwa ia tidak melakukan tindak pidana korupsi.

\section{Salah satu contoh rekayasa :}

"suatu alibi bagi terdakwa ialah jika pada waktu perbuatan korupsi dilakukan terdakwa tidak melakukan delik korupsi (delic action), ia tidak berada pada waktu dilakukan perbuatan (tempus delecty) maupun ia tidak melakukan perbuatan yang diuraikan dalam ketentuan Pasal 55 dan/atau Pasal 56 
KUHP, serta Pasal 480 KUHP, pada saat/ waktu (tempus delecty), perbuatan terjadi dilakukan/atau disekitar tempat (locus delecty) perbuatan tersebut dilakukan.

\section{Syarat Kedua}

Syarat yang kedua adalah terdakwa berkewajiban memberikan keterangan tentang asal usul/perolehan hak atau pelepasan hak atas harta benda pribadinya, anak, isterinya, maupun orang lain atau korporasi yang diduga berkaitan dengan delik korupsi tersebut.

Adapun mengenai perolehan atau pelepasan hak itu mengenai kapan, bagaimana, dan siapa-siapa saja yang terlibat dalam perolehan atau pelepasan hak itu serta, mengapa, dan sebab-sebab apa perolehan atau peralihan itu terjadi. Dengan demikian penggunaan hak terdakwa ini dapat menguntungkan dan merugikan kedudukan terdakwa dalam pembelaannya.

\section{Sikap Jaksa Selaku Penuntut Umum}

Penuntut umum tidak mempunyai hak tolak atas hak yang diberikan undang-undang kepada terdakwa, namun tidak berarti Jaksa Penuntut Umum tidak memiliki hak untuk menilai dari sudut pandang Jaksa Penuntut
Umum dalam requistornya.

Apabila terdakwa dapat membuktikan hak tersebut, bahwa ia tidak terbukti melakukan korupsi, sebab Jaksa Penuntut Umum masih ber-kewajiban untuk membuktikan dakwaan-nya. Karena Jaksa Penuntut Umum masih tetap wajib membuktikan dakwaannya.

Bagi Jaksa Penuntut Umum, ia tetap berkewajiban membuktikan dakwaannya sesuai dengan teori negative menurut undang-undang adalah pada terdakwa ada kesalahan atau tidak dan apa terdakwa inilah yang melakukan perbuatan.

\section{Sikap Hakim}

Terhadap keterangan terdakwa itu, hakim akan mempertimbangkan semuanya dan sikap hakim bebas dalam menentukan pendapatnya, yaitu :

a. Keterangan terdakwa itu hanya berlaku bagi terdakwa sendiri saja;

b. Kalau keterangan terdakwa terbukti tidak melakukan delik korupsi, maka keterangan itu dipakai sebagai hal yang menguntungkan pribadi terdakwa; c. Apabila terdakwa tidak dapat 
PERSPEKTIF Volume XI No.3 Tahun 2006 Edisi Juli

membuktikan tentang kekayaan yang tidak seimbang atau sebanding dengan penghasilan atau sumber penambahan kekayaan, maka keterangan itu dapat dipergunakan untuk memperkuat bukti yang sudah ada, bahwa terdakwa telah melakukan tindak pidana korupsi, atau dengan kata lain, keterangan itu merugikan bagi nkedudukan terdakwa.

\section{Perhatian Bagi Penegak Hukum}

Perlu diperhatikan dalam menerapkan teori negative menurut undang-undang (negatief wetelijk) terdapat dua hal yang merupakan syarat, yakni :

a. Wattelief, oleh karena alat-alat bukti yang sah dan ditetapkan oleh undang-undang.

b. Negatief, oleh karena dengan alat-alat bukti yang sah dan ditetapkan oleh undang-undang saja belum cukup untuk memaksa hakim pidana menganggap bukti sudah diberi-kan, akan tetapi masih dibutuhkan keyakinan hakim.
Dengan demikian antara alat-alat bukti dengan keyakinan hakim diharuskan adanya hubungan causal (sebab-akibat).

Dalam Pasal 183 KUHAP, mensyaratkan adanya 2 alat bukti yang sah dan ditetapkan oleh undang-undang dan keyakinan hakim, bahwa tindak pidana telah terjadi dan terdakwalah yang bersalah melakukannya.

\section{PENUTUP}

Bahwa pembuktian terbalik menurut UU No. 20 Tahun 2001 Jo UU No. 31 Tahun 1999 yang bersifat terbatas, dan berimbang, artinya terdakwa mempunyai hak untuk membuktikan bahwa ia tidak melakukan tindak pidana korupsi;

Bahwa selain terdakwa mempunyai hak untuk membuktikan, ia wajib memberikan keterangan tentang seluruh harta bendanya dan harta isteri atau suami, anak, dan harta benda setiap orang/atau korporasi yang diduga mempunyai hubungan dengan perkara

Bahwa dengan tidak dapatnya terdakwa untuk membuktikan tentang kekayaan yang tidak seimbang, maka terdakwa dapat diduga dan telah melakukan tindak pidana korupsi 
PERSPEKTIF Volume XI No.3 Tahun 2006 Edisi Juli

Bahwa untuk membuktikan salah dan tidaknya terdakwa telah melakukan tindak pidana korupsi, jaksa selaku penuntut umum tetap berkewajiban untuk membuktikan dakwaannya;

Bahwa hakim dalam menangani perkara korupsi, sikap hakim bebas dalam menentukan pendapatnya, sebagai berikut :

Sikap terdakwa itu hanya berlaku bagi terdakwa sendiri Jika keterangan terbukti tidak melakukan delik korupsi, maka keterangan itu dipakai sebagai hal yang menguntungkan pribadinya; Jika terdakwa tidak dapat membuktikan tentang kekayaan yang tidak seimbang atau sebanding dengan penghasilan atau sumber penambahan kekayaan, maka keterangan itu dapat dipergunakan untuk memperkuat bukti yang sudah ada, bahwa terdakwa telah melakukan tindak pidana korupsi, atau dengan kata lain, keterangan itu merugikan bagi kedudukan terdakwa.

\section{DAFTRA PUSTAKA}

B de Bosh-Kemper, dalam R. Tresna, Komentar Atas Reglemen Hukum Acara Didalam Pemeriksaan Dimuka Pengadilan Negeri. Jakarta. NV.

Indriyanto Seno Adji, Sistem Pembuktian Terbalik: Meminimalisasi Korupsi Di Indonesia. Varia Peradilan. Vol. 1, No. 2, Juni 2001.

Komisis Pemberantasan Tindak Pidana Korupsi, Undang - Undang Nomor 30 Tahun 2002, Varia Peradilan, Majalah Hukum, XVII, No. 210, Maret 2003.

Wiryono Pradjodokiro, Hukum Acara Pidana DI Indonesia, Bandung, Sumur, 1962. 